|| ISSN(online): 2589-8698 || ISSN(print): 2589-868X ||

International Journal of Medical and Biomedical Studies

Available Online at www.ijmbs.info

NLM (National Library of Medicine ID: 101738825)

Index Copernicus Value 2019: 79.34

\title{
A PROSPECTIVE EVAlUATION OF HEPATIC PARAMETERS IN CONGESTIVE HEART FAILURE PATIENTS
}

\author{
Dr. Chirag Agarwal ${ }^{1}$, Dr. Shashank Mohan ${ }^{2}$, Dr. Ashwini Kumar ${ }^{3}$ \\ ${ }^{1} P G 2^{\text {nd }}$ Year, Department of General Medicine, Nalanda Medical College and Hospital, Patna, Bihar, India \\ ${ }^{2} \mathrm{PG} 2^{\text {nd }}$ Year, Department of General Medicine, Nalanda Medical College and Hospital, Patna, Bihar, India \\ ${ }^{3} P G 3{ }^{\text {nd }}$ Year, Department of General Medicine, Nalanda Medical College and Hospital, Patna, Bihar, India
}

Article Info: Received 04 January 2021; Accepted 29 January 2021

DOI: https://doi.org/10.32553/ijmbs.v5i1.1707

Corresponding author: Dr. Chirag Agarwal

Conflict of interest: No conflict of interest.

\section{Abstract}

Aim: The aim of the study to find out the prevalence of liver function abnormalities in heart failure patients, pattern of elevation of liver enzymes and correlation of liver function tests with etiology, duration and of heart failure.

Material and methods: This is a prospective study was conducted in the Department of General Medicine Nalanda Medical College and Hospital, Patna, Bihar, India from October 2019 to March 2020. The hepatic biochemical parameters like serum bilirubin (direct, indirect and total), serum AST and ALT, Serum alkaline phosphatase, Serum proteins and Prothrombin time were estimated.

Results: In present study mean age of patient was $57.68 \pm 11.78$ years. Maximum number of patients was from 50 to 75 years of age that is $45(56.25 \%)$. As per NYSA classification maximum number of cases were class II (46.25\%) followed by class III $(26.25 \%)$. Percentage of patients with class I were $18.75 \%$ and class IV were $8.75 \%$. Maximum number of patients has disease from to 4-year duration that is $66.25 \%$. Regarding clinical presentation of patient's jaundice was present in $27.5 \%$, hepatomegaly which was most commonly present that was $47.5 \%$, ascites was present in $28.75 \%$ and congested hepatomegaly in USG (41.25\%). Regarding hepatic biochemical parameters there is significant variation in serum bilirubin $(\mathrm{mg} / \mathrm{dl})$ parameter as per progress in class of heart failure $(\mathrm{p}=0.001)$. Serum bilirubin was $3.88 \pm 1.57 \mathrm{mg} / \mathrm{dl}$ in class IV and least in class I that is $1.132 \pm 0.28 \mathrm{mg} / \mathrm{dl}$. Serum AST was highest in class IV $161.14 \pm 25.85$ IU and least in class I that is $35.68 \pm 11.87 \mathrm{IU}(\mathrm{p}=0.001)$. Serum ALT was highest in class IV $188.98 \pm 35.85 \mathrm{IU}$ and least in class I that is $35.11 \pm 10.56$ $(\mathrm{p}=0.001)$. Serum ALP was highest in class IV 62.27 $\pm 15.32 \mathrm{IU}$ and least in class I that is $39.48 \pm 8.85$ ( $\mathrm{p}=0.01$ ). Serum total protein $(\mathrm{g} / \mathrm{dl})$ was decreased as the heart failure progressed least in class IV $3.59 \pm 1.47 \mathrm{~g} / \mathrm{dl}$ and highest in class I that is $6.78 .14 \pm 2.14 \mathrm{gm} / \mathrm{dl}(\mathrm{p}=0.05)$. Serum albumin $(\mathrm{g} / \mathrm{dl})$ was least in class IV $2.79 \pm 0.82 \mathrm{~g} / \mathrm{dl}$ and highest in class I that is $4.75 \pm 0.85 \mathrm{gm} / \mathrm{dl}(\mathrm{p}=0.034)$. Prothrombin time $(\mathrm{sec})$ was highest in class IV $23.24 \pm 6.11$ sec and least in class I that is $13.12 \pm 3.36 \mathrm{sec}(\mathrm{p}=0.01)$.

Conclusion: We conclude that heart failure was common in fifth and sixth decade of life and there was male predominance. Congested hepatomegaly was common presentation jaundice and ascites was also common. Change in biochemical parameters was increased with severity and duration of heart disease.

Keywords: heart failure, hepatomegaly, biochemical parameters

\section{Introduction}

Heart failure $(\mathrm{HF})$ is a widespread and serious problem that has been reported in many countries. ${ }^{1}$ Nohria-Stevenson profiles demonstrated the clinical importance of assessments of perfusion ("cold" versus "warm"), as well as congestion ("wet" versus "dry"). 2,3 The abdominal compartment, which includes the liver, splanchnic vasculature, gut, and so on, has recently been investigated to determine whether it significantly contributes to a deranged cardiac function as well as multiple organ function in patients with $\mathrm{HF}^{4,5} \mathrm{HF}$ causes liver dysfunction with a combination of reduced arterial perfusion and passive congestion, and this association is called "cardiohepatic interaction." tests (LFTs), liver dysfunction, such as the elevation of serum bilirubin, ALP, gamma-glutamyl transferase, AST, and ALT, frequently occurs in HF related to reduced arterial perfusion and passive congestion, and is associated with disease severity and prognosis. ${ }^{5,7,8}$ Liver congestion attributable to increased central venous pressure might directly contribute to a state of impaired natriuresis. ${ }^{5,9}$ In addition, elevated central venous pressure and right atrial pressure (RAP) may contribute to cholestatic abnormalities (elevated bilirubin, ALP, gamma-glutamyl transferase), as well as impairment of both hepatocyte function and liver reserve in patients with $\mathrm{HF}^{6}{ }^{6}$ With regard to image testing, evaluation of chronic liver disease based on liver stiffness (LS) assessed by transient elastography has attracted growing interest in the field of clinical hepatology. LS is 
recently calculated on the basis of shear wave velocity measurements, and is used as a noninvasive method to assess liver fibrosis. It has been reported that LS is highly reflective of right-sided filling pressure, and might be a marker of liver congestion in patients with HF. ${ }^{10,11}$ Congestive hepatopathy ${ }^{6,7}$ attributable to $\mathrm{HF}$ causes functional abnormalities of the liver, and increased LS indicates adverse prognosis. ${ }^{12}$ Fouad et al has concluded that heart failure is associated with manifestations of liver failure and laboratory data specific to ischemic hepatitis or congestive hepatopathy. Auer et al has reported that elevated liver enzymes are common in patients with HF. Saner et al has concluded that congestive heart failure should always be considered as a possible cause of acute liver failure. it is clear that hepatic abnormalities are associated with heart failure. With this view present study has been designed to study the prevalence of liver function abnormalities in heart failure patients, pattern of elevation of liver enzymes and correlation of liver function tests with etiology, duration and of heart failure.

\section{Material and methods}

This is a prospective study was conducted in the Department of General Medicine Nalanda Medical College and Hospital, Patna, Bihar, India from October 2019 to march 2020.

\section{Methodology}

Total 80 patients with clinically and echocardiographically diagnosed of heart failure were include in this study. Patients with pre-existing hepatic disorder, Use of hepatotoxic drug, Chronic alcoholic were exclude from this study.

All patients enrolled for this study was evaluated clinically and echocardiographically. Various demographic parameters like age sex duration of disease were recorded on predesigned Performa. The hepatic biochemical parameters like serum bilirubin (direct, indirect and total), serum AST and ALT, Serum alkaline phosphatase, Serum proteins and Prothrombin time were estimated. For estimation of above parameters ebra EM 200 biochemistry analyser was used. All parameters were compared based on NYSA classification and duration of disease. ${ }^{16,17}$

Statistical analysis

Data were recorded in excel sheet and statistical Analysis was done with software SPSS-14 version. Qualitative data were calculated as percentage and proportions and were analysed by chi-square test. Quantitative data were expressed as mean \pm SD and these data were analysed by unpaired student $t$ test. The $p$ value less than 0.05 were taken as significant

\section{Results}

In present study 80 patients with various class and duration of heart failure were enrolled for this study for evaluation of changes in hepatic parameters. In our study as per table 1 mean age of patient was $57.68 \pm 11.78$ years. Number of patients less than 25 years was $3(3.37 \%)$, from 25 to 50 years were $13(16.25 \%)$. Maximum number of patients was from 50 to 75 years of age that is $45(56.25 \%)$. Number of patients above 75 years of age was 19 (23.75\%). There was male predominance $58(72.5 \%)$. As per NYSA classification maximum number of cases were class II (46.25\%) followed by class III $(26.25 \%)$. Percentage of patients with class I were $18.75 \%$ and class IV were $8.75 \%$. Regarding duration of disease $12.5 \%$ patients have disease since less than one year. Maximum number of patients has disease from to 4year duration that is $66.25 \%$. Duration of disease was more than 4 year in $21.25 \%$ patients.

Table 1: Demography of patients with heart failure.

\begin{tabular}{|l|l|l|l|}
\hline \multicolumn{2}{|l|}{ Parameter } & Number & Percentage (\%) \\
\hline \multirow{3}{*}{$\begin{array}{l}\text { Age (mean 57.68 } \\
\text { year) }\end{array}$} & Below 25year & 3 & 3.37 \\
\cline { 2 - 4 } & 25 to 50 & 13 & 16.25 \\
\cline { 2 - 4 } & 50 to 75 & 45 & 56.25 \\
\cline { 2 - 4 } & Above 75 & 19 & 23.75 \\
\hline \multirow{4}{*}{ Sex } & M & 58 & 72.5 \\
\cline { 2 - 4 } & F & 22 & 27.5 \\
\hline \multirow{4}{*}{ Duration of disease } & Class I & 15 & 18.75 \\
\cline { 2 - 4 } & Class II & 37 & 46.25 \\
\cline { 2 - 4 } & Class III & 21 & 26.25 \\
\cline { 2 - 4 } & Class IV & 7 & 8.75 \\
\hline & Less than 1 year & 10 & 12.5 \\
\cline { 2 - 3 } & 1 to 4year & 53 & 66.25 \\
\cline { 2 - 3 } & More than 4year & 17 & 21.25 \\
\hline
\end{tabular}


Regarding clinical presentation of patient's jaundice was present in $27.5 \%$, hepatomegaly which was most commonly present that was $47.5 \%$, ascites was present in $28.75 \%$ and congested hepatomegaly in USG $(41.25 \%)$.

Table 2: Clinical presentation of patients with heart failure

\begin{tabular}{lll}
\hline Clinical parameter & $\mathbf{N}(\mathbf{n = 6 0 )}$ & Percentage (\%) \\
\hline Jaundice & 21 & 27.5 \\
\hline Hepatomegaly & 38 & 47.5 \\
\hline Ascites & 23 & 28.75 \\
\hline Congested hepatomegaly in USG & 33 & 41.25 \\
\hline
\end{tabular}

egarding hepatic biochemical parameters there is significant variation in serum bilirubin $(\mathrm{mg} / \mathrm{dl})$ parameter as per progress in class of heart failure $(\mathrm{p}=0.001)$. Serum bilirubin was $3.88 \pm 1.57 \mathrm{mg} / \mathrm{dl}$ in class IV and least in class I that is $1.132 \pm 0.28 \mathrm{mg} / \mathrm{dl}$. Serum AST was highest in class IV $161.14 \pm 25.85 \mathrm{IU}$ and least in class I that is $35.68 \pm 11.87 \mathrm{IU}$ $(\mathrm{p}=0.001)$. Serum ALT was highest in class IV $188.98 \pm 35.85 \mathrm{IU}$ and least in class I that is $35.11 \pm 10.56$ $(p=0.001)$. Serum ALP was highest in class IV 62.27 \pm 15.32
IU and least in class I that is $39.48 \pm 8.85(\mathrm{p}=0.01)$. Serum total protein $(\mathrm{g} / \mathrm{dl})$ was decreased as the heart failure progressed least in class IV $3.59 \pm 1.47 \mathrm{~g} / \mathrm{dl}$ and highest in class I that is $6.78 .14 \pm 2.14 \mathrm{gm} / \mathrm{dl}(\mathrm{p}=0.05)$. Serum albumin $(\mathrm{g} / \mathrm{dl})$ was least in class IV $2.79 \pm 0.82 \mathrm{~g} / \mathrm{dl}$ and highest in class I that is $4.75 \pm 0.85 \mathrm{gm} / \mathrm{dl}(\mathrm{p}=0.034)$. Prothrombin time (sec) was highest in class IV $23.24 \pm 6.11 \mathrm{sec}$ and least in class I that is $13.12 \pm 3.36 \mathrm{sec}(\mathrm{p}=0.01)$.

Table 3: Liver biochemical parameters of patients in comparison with class of heart failure

\begin{tabular}{llllll}
\hline Parameter & Class I & Class II & Class III & Class IV & P value \\
\hline Serum bilirubin $(\mathrm{mg} / \mathrm{dl})$ & $1.132 \pm 0.28$ & $1.64 \pm 0.62$ & $2.35 \pm 0.74$ & $3.88 \pm 1.57$ & 0.001 \\
\hline Serum AST IU & $35.68 \pm 11.87$ & $52.75 \pm 20.68$ & $89.57 \pm 13.89$ & $161.14 \pm 25.85$ & 0.001 \\
\hline Serum ALT IU & $35.11 \pm 10.56$ & $45.23 \pm 11.24$ & $85.36 \pm 13.22$ & $188.98 \pm 35.85$ & 0.0001 \\
\hline Serum ALP IU & $39.48 \pm 8.85$ & $43.26 \pm 12.55$ & $53.83 \pm 11.86$ & $62.27 \pm 15.32$ & 0.01 \\
\hline Serum total protein $(\mathrm{g} / \mathrm{dl})$ & $6.78 .14 \pm 2.14$ & $5.34 \pm 2.11$ & $5.05 \pm 2.05$ & $3.59 \pm 1.47$ & 0.05 \\
\hline Serum albumin $(\mathrm{g} / \mathrm{dl})$ & $4.75 \pm 0.83$ & $3.29 \pm 0.79$ & $3.12 \pm 0.51$ & $2.79 \pm 0.82$ & 0.034 \\
\hline Prothrombin time $(\mathrm{sec})$ & $13.12 \pm 3.36$ & $15.06 \pm 8.95$ & $18.23 \pm 4.31$ & $23.24 \pm 6.11$ & 0.01 \\
\hline
\end{tabular}

Regarding comparison of liver biochemical parameters in patients with duration of heart failure as per table 4 it is clear that serum bilirubin was increased with the duration of disease. The mean value of serum bilirubin $(\mathrm{mg} / \mathrm{dl})$ in patients with duration of disease more than 4 year was $3.11 \pm 1.17 \mathrm{mg} / \mathrm{dl}$ was significantly higher than the patients with duration of disease less than 4 year significantly $(p=0.02)$. Serum AST was highest with duration of disease more than 4 year $112 \pm 26.34$ IU and least in patients with duration of disease less than 4 year that is $40.57 \pm 8.94 \mathrm{IU}$ $(p=0.001)$. Serum ALT was highest with duration of disease more than 4 year $159.87 \pm 26.38$ IU and least in patients with duration of disease less than 4 year that is $34.12 \pm 8.94 \mathrm{IU}$ $(p=0.001)$. Serum ALP IU was highest with duration of disease more than 4 year $60.12 \pm 10.14$ IU and least in patients with duration of disease less than 4 year that is $40.15 \pm 4.57$ IU $(p=0.02)$. Serum total protein $(\mathrm{g} / \mathrm{dl})$ was least with duration of disease more than 4 year $4.12 \pm 2.22$ $\mathrm{g} / \mathrm{dl}$ and normal in patients with duration of disease less than 4 year that is $6.77 \pm 1.58 \mathrm{~g} / \mathrm{dl}(\mathrm{p}=0.029)$. Serum albumin $(\mathrm{g} / \mathrm{dl})$ was least with duration of disease more than 4 year $2.77 \pm 1.44 \mathrm{~g} / \mathrm{dl}$ and normal in patients with duration of disease less than 4 year that is $3.84 \pm 0.79 \mathrm{~g} / \mathrm{dl}(\mathrm{p}=0.14)$. Prothrombin time $(\mathrm{sec})$ was highest with duration of disease more than 4 year $20.11 \pm 3.22 \mathrm{sec}$ and least in patients with duration of disease less than 4 year that is $13.79 \pm 2.68 \mathrm{sec}$ $(\mathrm{p}=0.01)$.

Table 4: Liver biochemical parameters of patients in comparison with duration of heart failure

\begin{tabular}{lllll}
\hline Parameter & less than 1 year & 1 to 4 years & more than 4 years & P value \\
\hline Serum bilirubin $(\mathrm{mg} / \mathrm{dl})$ & $1.09 \pm 0.4$ & $1.98 \pm 0.56$ & $3.11 \pm 1.17$ & 0.02 \\
\hline Serum AST IU & $40.57 \pm 8.94$ & $48.11 \pm 6.14$ & $112 \pm 26.34$ & 0.001 \\
\hline Serum ALT IU & $34.12 \pm 8.94$ & $79.65 \pm 8.45$ & $159.87 \pm 26.38$ & 0.000 \\
\hline Serum ALP IU & $40.15 \pm 4.57$ & $44.85 \pm 10.14$ & $60.12 \pm 10.14$ & 0.02 \\
\hline Serum total protein $(\mathrm{g} / \mathrm{dl})$ & $6.77 \pm 1.58$ & $5.94 \pm 1.89$ & $4.12 \pm 2.22$ & 0.029 \\
\hline Serum albumin $(\mathrm{g} / \mathrm{dl})$ & $3.84 \pm 0.79$ & $3.01 \pm 1.22$ & $2.77 \pm 1.44$ & 0.14 \\
\hline Prothrombin time $(\mathrm{sec})$ & $13.79 \pm 2.68$ & $15.76 \pm 3.45$ & $20.11 \pm 3.22$ \\
\hline
\end{tabular}




\section{Discussion}

Heart failure as a cause of acute liver failure is less documented and poorly understood condition. Auer et al have concluded that hepatic enzymes are elevated in heart failure patients. Pattern of change in hepatic enzyme differ as per in patients with chronic and acute decompensate HF and are surrogates of the type of hemodynamic alterations. $^{13,14}$ Shah et al has concluded that hepatic injury as a consequence of heart failure is common but less recognized syndrome. ${ }^{18}$ In present study we have observed that mean age of patient was $57.68 \pm 11.78$ years and maximum number of patients was from 50 to 75 years of age. There was male predominance. This finding is supported by Van Deursen et al. ${ }^{19}$ Most of the patients were in class III and class IV group and duration of disease was from 1 with higher class of heart failure than class I. This corroborates with the work of Allen et al. ${ }^{20}$

We have observed that hepatic biochemical parameters were significantly elevated in patients with higher class of heart failure than class I. in our study serum total protein ( $\mathrm{g} / \mathrm{dl})$ was decreased as the heart failure progressed least in class IV $3.59 \pm 1.47 \mathrm{~g} / \mathrm{dl}$ and highest in class I that is $6.78 .14 \pm 2.14 \mathrm{gm} / \mathrm{dl}(\mathrm{p}=0.05)$. Serum albumin $(\mathrm{g} / \mathrm{dl})$ was least in class IV $2.79 \pm 0.82 \mathrm{~g} / \mathrm{dl}$ and highest in class $\mathrm{I}$ that is $4.75 \pm 0.85 \mathrm{gm} / \mathrm{dl}(\mathrm{p}=0.034)$. Serum total protein $(\mathrm{g} / \mathrm{dl})$ and albumin was significantly decreased in class III and class IV patients in comparison to class I and class II to 4 years. Alvarez has concluded that may cause elevations of liver enzymes and both direct and indirect serum bilirubin and marked elevations in serum aminotransferases which support our study. ${ }^{21}$ Nikolaou et al has concluded that Abnormal LFTs were present in about a half of patients presenting with heart failure which corroborates with our finding ${ }^{22}$ Samsky et al has reported that severity of hepatic damage increases with duration of disease which supports our study. ${ }^{23}$ Naschitz et al has concluded that the spectrum of heart diseases affecting the liver includes mild alterations of liver function tests in heart failure, cardiogenic ischemic hepatitis, congestive liver fibrosis, and cardiac cirrhosis which progress with the progress of disease which support our study. has reported that liver function abnormalities remain common in patients with congestive heart failure but are generally small in magnitude and not associated with clinically apparent hepatic disease which contradict our study. ${ }^{24}$

\section{Conclusion}

We can conclude that heart failure was common in fifth and sixth decade of life and there was male predominance. Congested hepatomegaly was common presentation jaundice and ascites was also common. Change in biochemical parameters was increased with severity and duration of heart disease.

\section{Reference}

1. Ponikowski $\mathrm{P}$, Voors AA, Anker SD, Bueno $\mathrm{H}$,
Cleland JG, Coats AJ, Falk V, Gonzalez-Juanatey JR, Harjola VP, Jankowska EA, et al.; Authors/Task Force M and Document R. 2016 ESC guidelines for the diagnosis and treatment of acute and chronic heart failure: the Task Force for the Diagnosis and Treatment of Acute and Chronic Heart Failure of the European Society of Cardiology (ESC). Developed with the special contribution of the Heart Failure Association (HFA) of the ESC. Eur J Heart Fail. 2016;18:891-975.

2. Nohria A, Tsang SW, Fang JC, Lewis EF, Jarcho JA, Mudge GH, Stevenson LW. Clinical assessment identifies hemodynamic profiles that predict outcomes in patients admitted with heart failure. J Am Coll Cardiol. 2003;41:1797-1804.

3. Ikeda Y, Ishii S, Yazaki M, Fujita T, Iida Y, Kaida T, Nabeta T, Nakatani E, Maekawa E, Yanagisawa T, et al. Portal congestion and intestinal edema in hospitalized patients with heart failure. Heart Vessels. 2018;33:740-751.

4. Sharma K, Kass DA. Heart failure with preserved ejection fraction: mechanisms, clinical features, and therapies. Circ Res. 2014;115:79-96.

5. Verbrugge FH, Dupont M, Steels P, Grieten L, Malbrain M, Tang WH, Mullens W. Abdominal contributions to cardiorenal dysfunction in congestive heart failure. J Am Coll Cardiol. 2013;62:485-495.

6. Samsky MD, Patel CB, DeWald TA, Smith AD, Felker GM, Rogers JG, Hernandez AF. Cardiohepatic interactions in heart failure: an overview and clinical implications. J Am Coll Cardiol. 2013;61:2397-2405.

7. Moller S, Bernardi M. Interactions of the heart and the liver. Eur Heart J. 2013;34:2804-2811.

8. Abe S, Yoshihisa A, Takiguchi M, Shimizu T, Nakamura Y, Yamauchi H, Iwaya S, Owada T, Miyata M, Sato T, et al. Liver dysfunction assessed by model for end-stage liver disease excluding INR (MELD-XI) scoring system predicts adverse prognosis in heart failure. PLoS One. 2014;9:e100618.

9. Takiguchi M, Yoshihisa A, Miura S, Shimizu T, Nakamura Y, Yamauchi H, Iwaya S, Owada T, Miyata M, Abe $\mathrm{S}$, et al. Impact of body mass index on mortality in heart failure patients. Eur J Clin Invest. 2014;44:1197-1205.

10. Soloveva A, Kobalava Z, Fudim M, Ambrosy AP, Villevalde S, Bayarsaikhan M, Garmash I, Naumenko M. Relationship of liver stiffness with congestion in patients presenting with acute decompensated heart failure. J Card Fail. 2019;25:176-187.

11. Taniguchi T, Sakata Y, Ohtani T, Mizote I, Takeda Y, Asano Y, Masuda M, Minamiguchi H, Kanzaki M, Ichibori Y, et al. Usefulness of transient elastography for noninvasive and reliable estimation of right-sided filling pressure in heart failure. Am J Cardiol. 2014;113:552-558.

12. Colli A, Pozzoni P, Berzuini A, Gerosa A, Canovi C, 
Molteni EE, Barbarini M, Bonino F, Prati D. Decompensated chronic heart failure: increased liver stiffness measured by means of transient elastography. Radiology. 2010;257:872-878.

13. Fouad YM, Yehia R. Hepato-cardiac disorders. World J Hepatol. 2014;6(1):41-54.

14. Auer J. What does the liver tell us about the failing heart? Eur Heart J. 2013;34(10):711-4.

15. Heuer M, Meyer M. When the heart kills the liver: acute liver failure in congestive heart failure. Eur $\mathrm{J}$ Med Res. 2009; 14:541.

16. Yancy CW. 2013 ACCF/AHA Guideline for the Management of Heart Failure: A Report of the American College of Cardiology Foundation/American Heart Association Task Force on Practice Guidelines. Circulation. 2013;128;16.

17. The Criteria Committee of the New York Heart Association. Nomenclature and Criteria for Diagnosis of Diseases of the Heart and Great Vessels, $9^{\text {th }}$ ed. Boston, Mass: Little, Brown \& Co; 1994:253-6.

18. Shah SC, Sass DA. Cardiac Hepatopathy. A review of liver dysfunction in heart failure. Liver Res Open J. 2015;1(1):1-10

19. Van deursen VM, Damman K, Hillege H, Van beek AP, Van veldhuisen DJ, Voors AA. Abnormal Liver
Function in Relation to Hemodynamic Profile in Heart Failure Patients. J Cardiac Failure. 2010;16:1.

20. Allen LA, Felker GM, Pocock S. Liver function abnormalities and outcome in patients with chronic heart failure: data from the Candesartan in Heart Failure: Assessment of Reduction in Mortality and Morbidity (CHARM) program. Eur J Heart Fail. 2009;11(2):170-7.

21. Alvarez AM, Mukherjee D. Liver abnormalities in cardiac diseases and heart failure. Int $\mathbf{J}$ Angiol. 2011;20(3):135-42.

22. Nikolaou M, Parissis J, Yilmaz MB, Seronde M-F, Kivikko M, Laribi $S$ et al Liver function abnormalities, clinical profile, and outcome in acute decompensated heart failure. Eur Heart J. 2013;34(10):742-9.

23. Samsky MD, Patel CB, De Wald TA, Smith AD, Felker GM, Rogers JG et al. Cardiohepatic Interactions in Heart Failure an Overview and Clinical Implications. JACC. 2013;61(24):2397-405.

24. Naschitz JE, Slobodin G, Lewis RJ, Zuckerman E, Yeshurun D. Heart diseases affecting the liver and liver diseases affecting the heart. Am Heart J. 2000;140(1):111-20. 